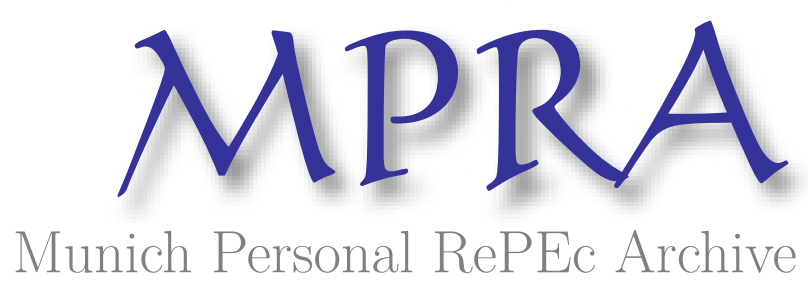

\title{
On the Determinants of a Country's Creditworthiness - The Case of Israel: 1971 to 1983
}

Gottlieb, Daniel

International Monetary Fund

4 December 1987

Online at https://mpra.ub.uni-muenchen.de/3147/

MPRA Paper No. 3147, posted 09 May 2007 UTC 


\section{IMF WORKING PAPER}

MTR rits

ifilitit $1 ;-130$

(ij)
This is a working paper and the author would welcome any comments on the present text. Citations should refer to an unpublished manuscript, mentioning the author and the date of issuance by the International Monetary Fund. The views expressed are those of the author and do not necessarily represent those of the Fund.

WP $/ 87 / 82$

INTERNATIONAL MONETARY FUND

European Department

On the Determinants of a Country's Creditworthiness The Case of Israe1: 1971 to 1983

Prepared by Daniel Gottlieb*

Authorized for Distribution by Adalbert Knöbl

December 4, 1987

\begin{abstract}
This paper assesses an economy's default risk on its international debt by considering different approaches, prevalent in the literature. Unlike in multi-country studies, these data comprise reported loans to one economy only. This is useful since the country's macroeconomic development is the common factor in all observations. The study suggests that for Israeli data the traditional approach, stressing an economy's ability to repay the external debt, performed better than the more recent approach emphasizing the borrowing country's costs and benefits from default, reflecting its willingness to repay debt. Policy considerations conclude the study.
\end{abstract}

JEL classification number:

4330

* The first version was written at the Research Department of the Bank of Israel. Helpful comments were provided by Giora Hanoch, Joshua Aizenman, and G. Tersman. I also thank ofira Levy-Hevroni for research assistance and Shalom Hershko for providing the data. 
I. Introduction

II. Cost-Benefit Versus Debt-Service Capacity--Two Competing Views

1. The cost-benefit approach

2. The debt-service capacity approach

3. Comparison of the two approaches

4. Empirical results

5. Some pollcy issues

III. Conclusions

Text Tables

1. Determinants of Creditworthiness

13

2. Comparison between the two Approaches

3. Average Conditions on the Loan Contracts, 1971 to 1983

4. Comparison of the Performance of CBA and DSCA

5. Regression Results of Equation (3)--The DSCA

6. Selected Regressions

7. Estimates of Creditworthiness (c) and its

Percentage Change over Time 


\section{Summary}

This paper analyzes Israel's creditworthiness in the years 1971-83 in light of the recent literature on this subject. One approach views the default (or rescheduling) on a country's external debt as a choice of the borrower, who acts rationally by weighing the costs and benefits of debt repudiation. The other approach, referred to in the paper as the debt-service capacity approach, perceives default as the culmination of an unintended deterioration in the borrower's capacity to service his debt. The paper suggests that this distinction implies different sets of explanatory variables, depending on the favored view of the determinants of default risk. The sets differ with respect not only to the relevant variables included, but also to specific variables. It is frequently argued that specific variables, said to be relevant in both approaches, actually have opposite effects on creditworthiness.

The data used here refer to dollar loans received by Israeli private and public borrowers from foreign commercial banks. Though a number of studies have used pooled data on loans from the international banking system, this study uses pooled data on a single economy. This eliminates the possible weakness of cross-sectional data on different countries, arising from definitional problems and the uneven quality of the data across countries, as well as other problems, such as country-specific institutional differences.

The study suggests that for the observed Israeli data the traditional approach, stressing the capacity of an economy to repay the external debt, performed better than the more recent approach that emphasizes the borrowing country's costs and benefits from default, reflecting the debtor's willingness to repay debt.

The paper concludes by suggesting two policy considerations. First, since bankers appear to evaluate macroeconomic developments by their impact on debt-service capacity rather than on the borrower's costs and benefits from debt repudiation, the major issue facing the borrowing country is that of monitoring its debt-service capacity. Second, in view of the importance of reserves as a determinant of creditworthiness, a debtor country may consider borrowing for the sake of reserve accumulation or reserve pegging. 
•

• 


\section{Introduction}

This paper analyzes Israel's creditworthiness in the years 1971 to 1983 in light of the recent 1 iterature on this subject. One approach views the default (or rescheduling) on a country's external debt as a choice situation of the borrower, who acts rationally by weighing costs and benefits from debt repudiation (henceforth CBA). The other, referred to here as the debt-service capacity approach (DSCA), apprehends default as the culmination of an unintended deterioration in the borrower's capacity to service his debt. We suggest that this distinction implies different sets of explanatory variables, depending on the favored view on the determinants of default risk. The sets differ not only with respect to the relevant variables included; but also specific variables, which are said to be relevant in both views, are frequently argued to have opposite effects on creditworthiness.

The data used here refer to dollar-loans received by Israeli private and public borrowers from foreign commercial banks. Though a number of studies have used pooled data on loans from the international banking system, this study uses pooled data on a single economy. This eliminates possible weaknesses of cross-sectional data on different countries, arising from definitional problems, varying quality of the data across countries, as well as other problems such as countryspecific institutional differences.

Our empirical findings suggest that the DSCA peforms well, while the CBA, which emphasizes the debtor's willingness, rather than his ability to repay his debt does not fit the Israeli data. The set of explanatory variables is divided into three distinct groups. The first two consist of variables, common to both approaches. However, while the variables of the first subset affect default probability in the same direction according to both views, the second subset, consists of variables with opposite effects. The third subset includes those variables which are unique to either of the two approaches. The empirical evidence suggests that the DSCA performs better in each of the three subsets.

After discussing the different approaches in the next section, the empirical results are reported in Section 4. Possible uses of the results for purposes of debt-management policy are addressed in section 5. The model underlying the reduced form equation is described in Appendix I. Definitions and data sources are given in Appendix II. Further regressions are reported in Appendix III.

\section{Cost-Benefit Versus Debt-Service Capacity-- Two Competing Views}

\section{The cost-benefit approach}

For many years the 1 iterature on optimal borrowing by national economies on the one hand and the mostly empirical studies on default on 
international debt on the other hand developed independently of each other. Bardhan (1967), Hamada (1969), Bade (1972), Hanson (1974), and others developed models using optimal control theory to derive optimal paths of foreign debt accumulation. Practically all authors accounted for the default problem either implicitly or explicitly by assuming a loan supply schedule with a rising cost of foreign capital as a function of debt size. Bardhan also allowed for disutility in the welfare function, caused by foreign debt accumulation. Freeman (1979) explicitly introduced benefits and costs from debt repudiation (henceforth DR) by allowing the debtor to consider DR as a possible strategy, including its timing. In this model the borrower permanently compares a grand plan of investment-cum-default to one of investmentcum-compliance. The "naive" lenders are assumed not to be aware of any of this, since prior to the moment of default they are supposed to supply any amount of debt at the level of the safe interest rate. The debtor's capital cost is supposed to increase only after default has occurred. The defaulting economy's benefit is the "windfall gain" consisting of the outstanding debt, by which the country's equity capital is assumed to increase. According to Freeman then, the higher a borrower's long term growth intentions, the less likely is he to repudiate the debt within the planning period, since in that case consumption will be clustered more toward the end of the period and thus discounted more heavily by the higher post-default rate of interest. In reality the increase in the interest rate will probably not be of such discontinuity, but rather endogenously determined by the lender's expectations of default probability.

Eaton and Gersovitz (henceforth EG) (1981a) and (1981b) suggest that in absence of legal institutions, able to enforce international loan agreements, breached by sovereign governments, the market mechanism emerges in form of a threat of future exclusion from international capital markets. In the extreme case the cost of repudiation to the defaulting debtor is the loss in welfare due to his being forced into autarchy or at best barter in his foreign trade. The benefit resembles that in Freeman, though EG $(1981 \mathrm{a}, \mathrm{b})$ do not restrict themselves to the investment motive for foreign debt accumulation. According to EG (1981b) the demand for external debt derives from four major motives, namely the consumption, transactions, investment and adjustment 
motives. The higher the expected cost to the debtor due to intentional repudiation, the lower is his incentive to default, the reverse being true for the benefit from DR. $1 /$

According to the consumption motive of borrowing, an economy wishing to pursue a steady consumption path, has a strong incentive to secure free access to the foreign capital market. Thus the higher its income variability, the lower will be the incentive of DR (see proposition 4 in EG $(1981 \mathrm{a}))$. In this context an economy might wish to increase present borrowing in order to enjoy already part of its future income growth. Thus income growth should be positively related to the cost of default. $\underline{2} /$

Regarding the transactions motive, the debtor's incentive to invest in his "reputation" vis-à-vis the lender should be positively linked to some measure of the economy's "openness" to foreign markets. Such an indicator reflects the consumers' tastes for imported goods and services, the sensitivity of production factor unemployment to the steadiness of imports of raw materials, capital goods, spare parts, and of export demand. A commonly used indicator for openness is the ratio of imports to income. We use a measure of the volume of goods and services imports and exports relative to GNP.

As to the investment motive, investment opportunities, promising relatively high productivity in the borrowing country, are recognized as an important argument for debt accumulation. Sachs and Cohen (1982) show that in a two-period model with a constant penalty rate from debt repudiation, triggered by a random shock on the second period's output, lenders' credit ceilings will be positively related to the debtor's investment propensity especially if he precommits himself to an investment plan.

The adjustment motive is represented here by a measure of current account variability, implying that a large part of it is due to external

1/ According to this view, both the transversality condition (solvency constraint) and the liquidity constraint are assumed to hold at least implicitly, because otherwise debt repudiation cannot be viewed as a choice situation. The transversality condition is stated in Cooper and Sachs (1984, p. 5). It assumes the principal and interest payment on it to be smaller than the discounted sum of future trade balance surpluses at any point in time. The liquidity constraint requires the debt service, and other unavoidable expenditures in each period to be smaller than total foreign exchange receipts.

2/ EG (1981a) show that this growth effect might be ambiguous, depending on the elasticity of the marginal utility of income, since a high growth rate increases the extent to which future penalties are discounted. 
shocks affecting imports and exports, thus creating an incentive to secure future borrowing. Concluding this discussion we suggest that the following specification duly represents the cost benefit approach.

$$
\pi=\pi\left(\bar{D}, \bar{R}, \bar{g}_{y}, \bar{\sigma}_{y}, \text { open, dmpk, } \bar{\sigma}_{g s}^{-}\right)
$$

where $D=$ external debt, $R=$ reserves, $g_{y}=$ growth rate of GNP, $\sigma=$ variance of GNP from trend, open $=$ (imports + exports)/GNP, mpk = małginal product of capital, $\sigma_{0}=$ variance of the balance on goods and services from trend. The signs a above the variables indicate first derivatives.

\section{The debt-service capacity approach}

This approach excludes the possibility of a debtor country willingly repudiating its debt. Accordingly default is due to an unforeseen economic development which creates an unsustainable situation manifesting itself either in short-term illiquidity or in a long run problem of the country's economic structure, which eventually ends up in liquidity problems. While the CBA and the literature on optimal debt assume that the debtor's intertemporal budget constraint, which sets a 1 imit to his borrowing facilities, is satisfied, the DSCA deals with its violation, e.g., due to economic mismanagement, unanticipated external shocks or long run structural problems. Conceptually, then, the underlying assumptions of the DSCA and the CBA are mutually exclusive for a debtor country in a given period of time.

In the 1970s there were many studies which improved the more rudimentary growth-cum-debt approach outlined in Avromovic (1964) by the use of more sophisticated statistical procedures. The basic aim of this sort of study is to find empirical regularities, by the help of which debt-servicing problems can be predicted. Frank and Cline (1971), Feder and Just (1977a) and (1977b), Saini and Bates (1978), Mayo and Barrett (1978), Sargen (1976) and (1977), are but a few of several such studies. The relevant variables are typically chosen ad hoc. Table 1 1ists the hypothesized signs of the most commonly represented variables. The letters in parentheses, given next to the sign, indicates if that effect was found to be statistically insignificant (i) or opposite (o) to the hypothesized sign.

The probability of a sudden liquidity crisis diminishes with a higher current GNP, a lower ratio of imports to reserves or GNP and with a lower debt service in percent of exports. Long run solvency is supposed to improve with growth in exports and in output. Furthermore long run solvency is anticipated to improve with increased investment opportunities and a falling debt/output ratio. According to many studies of this type, an economy's ability to adjust to external shocks also deteriorates with increasing export variability, by causing irregularity in foreign exchange receipts. The inflation rate or money supply growth reflect more general indicators of lenders' confidence in the ability of economic management by the borrowing country's 
authorities. Average debt maturity is somewhat ambiguous, since on the one hand, a long debt maturity ascertains low periodical amortization payments, thus improving creditworthiness in the long run, but on the other hand, creates more rigidity of this flow, since there is not much possibility left for reducing amortization payments by substituting short maturities for longer ones in the short run.

A few remarks to Table 1. Angeloni and Brock (1980): Our table includes only their first four equations (see there, Table 1), since the others include a direct measure of default probability, from a regular survey by the "Institutional Investor," on the right hand side of the equation in additon to the other explanatory variables.

Feder and Just (1977a) (henceforth FJ) argue, similarly to Frank and $\mathrm{Cline}(1971)$, that a higher average debt maturity worsens creditworthiness because debt service cannot be alleviated in the short run by an immediate reduction in borrowing. Additionally to the conventi nal one, they also use a modified debt-service ratio, including all foreign exchange earnings rather than only exports. This variable was found significant. They performed a Logit-analysis on a binary variable of defaulting versus nondefaulting countries. In their (1977b) article, they use regression analysis on interest rates on Eurocurrency loans.

Saini and Bates (1978) introduced three additional variables to the standard list. (1) the current account balance minus the change in reserves, (2) this variable's integral over five years, and (3) net foreign assets of the banking system divided by the money supply. They compare the results from discriminant analysis (as in Frank and $\mathrm{Cline}$ ) and logit analysis on the mentioned binary variable.

A comprehensive survey of this literature can be found in McDonald (1982). These studies' main disadvantage compared to the Cost Benefit approach 1 ies in their ad hoc selection of variables indicating future default problems and in their lack of theoretical underpinnings. Kharas' work (1981) is an exception to this criticism. He outlined a macroeconomic growth model of a Harrod-Domar type, in which creditworthiness is derived as a function of the actual capital stock's deviation from the critical capital stock, the latter being defined as that level, which is sufficient to maintain creditworthiness at a given level of expected gross capital inflows and existing outstanding debt. Here the marginal propensity to invest out of net foreign capital inflows may have an ambiguous effect on creditworthiness since such foreign investment not only increases the capital stock, but also causes debt service to rise. In this approach a lengthening of average debt maturity unambiguously improves creditworthiness, contrarily to other studies, such as Frank and Cline (1971), Angeloni and Short (1980) and Edwards (1984).

Summarizing the various studies, we then suggest the following general specification to represent the DSCA: 


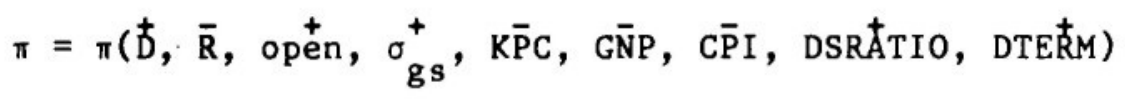

where the additional variables to those in (1) are $\mathrm{KPC}=$ per capita capital stocks, GNP = current GNP, CPI = consumer price inflation, DSRATIO = debt-service ratio, DTERM = average debt maturity.

\section{Comparison of the two approaches}

The discussed approaches differ in two important respects. Namely, in their variable selection and in their signs of the partial derivatives on default probability. These differences are summarized in Table 2 .

The variables can be divided into three groups. The first contains variables with the same specification with regard to their signs (though differing in their rationale). This group includes the external debt and reserves or indicators of investment opportunities (MPK). The second group, though consisting of similar variables, leads to opposite hypothesized effects on creditworthiness, such as for example openness and export variance. The last group includes all the variables which appear in only one of the specifications, such as the inflation rate, the debt service ratio, GNP, etc. In some instances, this distinction is not clear cut. For example, one may argue, that income growth and export growth may, in some cases, be proxies for each other. Noncompressible imports or the debt-service ratio may also have some bearing on the Cost Benefit Approach (though with opposite sign). It is however maintained here, that considering the distinct rationale and emphasis in the literature, underlying the specific variables, the suggested partition in Table 2 reflects these differences adequately. $1 /$

\section{Empirical results}

The technical issues and assumptions underlying the derivation of sovereign risk from data on interest rate differentials are discussed in Appendix I. This section compares the performance of the specifications derived from the two approaches.

The regressed data include all Israeli private and public sector floating-rate dollar loans received from foreign banks, as reported to

1/ The signs in parentheses in Table 2 indicate that the direction of the sign is consistent with the spirit of the approach without having necessarily been applied precisely in this form in the mentioned empirical studies. 
the Foreign Exchange Controller at the Bank of Israel over the years 1971 to 1983. 1/ The data presented here are unique among comparable studies in several respects. To our knowledge it is the first application to concentrate on the loans to a single country. Thus problems of differing definitions and quality of macroeconomic variables among different countries are avoided. Here these variables are by definition common to all the observations. Furthermore the analyzed data are nearly identical to the total population of this specific type of loans, rather than being a small sample of it.

Out of 524 bank loans received during those 13 years, some 70 percent were on a floating rate basis, mostly from the Eurodollar market. Only 19 contracts were 1 inked to the U.S. prime rate. The Government was the principal borrower over this period with over 80 percent of the floating rate loans. Table 3 summarizes a few facts. Maturities and grace period were usually shorter and spreads usually higher on floating rate loans than on fixed rate loans. This is especially apparent in the summary figures for all years. In other words, the floating rate loans are on average less favorable than the fixed rate loans. It should be emphasized here, that these loans constitute only a small fraction (2.5 percent in December 1983) of the total gross external debt of Israel, most of which is borrowed at much better terms. However, it does represent the marginal cost of foreign capital to the Israeli economy, relevant for public policy on the foreign debt. Public project appraisal has to account for it even if the specific project is financed by cheaper foreign loans, since this may in itself push other projects to the margin. The dependent variable $(r)$ is calculated as in equation $(1 \mathrm{~A})$, i.e., as the spread in percentage of the safe rate of interest on the day of contract. The safe rate is defined as the LIBOR for Eurodollar loans and as the PRIME rate for loans from the U.S. capital market. Due to severe discrepancies in the quality of the calculated spreads on fixed rate loans, as compared to reported spreads of the floating rate loans, empirical tests were performed on the latter only, since these data are much more homogeneous.

Several experiments were made to extract the appropriate time lag concerning the macroeconomic information reaching the lending bank's decision makers. We tested four possible lags, namely, one quarter,

1/ Several remarks are necessary: Foreign banks do not include subsidiaries of the Israeli banking system abroad. It would have been preferable to include also loans received at a fixed interest rate, however, there is a significant difference in the quality of the data. While on the floating rate loans the spread itself is recorded, this is not the case for the fixed rate loans. Our approximation of the spread on the latter loans clearly indicated that the safe rate of interest (to be deducted from the actual rate) was not precise enough, since even small daily or hourly changes influence the calculated spread noticeably. 
half a year, three quarters of a year and one year. The best results were achieved by applying a lag of three quarters of a year (see Table 8 , Appendix III). If The typical regression equation can be written

$$
\ln \left(\mathbf{r}_{n t}\right)=\alpha_{0}+\sum_{k=1}^{K} \alpha_{k} \times{ }_{k T}+\sum_{1=1}^{L} B_{1} z_{n l t}+u_{n t}
$$

where $\mathrm{n}$ are the individual loans in a given year, and $t$ is a daily time index. 2/ Loan-specific variables, such as the maturity of the loan, its size and grace period are denoted by $z_{1}, 1=1 \ldots .$. . Macroeconomic variables are denoted by $x_{k}, k=1 \ldots k$. The reference year at $t i m e t$, (due to the assumed lag) is denoted by $T, T=1970$ to 1983 . All the variables are defined in Appendix II.

The main regression results are reported in Table 4. In order to facilitate the interpretation of the regressions, a more general description of the variables is given in brackets.

The major conclusion is that the Israeli data for the observed period favor the debt-service-capacity approach in explaining observed spreads. This conclusion is drawn from the following results: (1) The variables ( $R P C D, R P C R$ ) are strongly significant in the hypothesized direction according to both views on creditworthiness, thus their inclusion is crucial, though it does not provide further information on the relative strength of either approach. (2) The estimated coefficients of the variables, common to both approaches, but having opposite a priori signs, are consistent with the DSCA (OPEN, VGS). The subset of variables, unique to each approach indicates that those added in the DSCA confirm the hypothesis. This includes the real per capita stock of capital (KPC), current GNP per capita (DGNPPC), the debt-service ratio (DSRATIO), and the inflation rate (CPI). On the other hand, the variance (VRGNP) and growth rate of GNP (GRPCY), which reflect the consumption motive discussed earlier and are typical for the CBA, appear with the wrong sign, and more so the coefficient of the variance (VRGNP) could be interpreted as supporting the DSCA, though this variable is not usually referred to in the mentioned studies. The marginal product of capital (MPK) is consistent with the CBA hypothesis, though its negative sign does not contradict the intuition of the DSCA.

1/ Such a reference period is introduced as following: Any loan granted in the first three quarters of the year is assumed to have been contracted upon the information on macroeconomic developments up to the end of the preceding year. Only in the last quarter is the lender assumed to know the data of the present year.

2/ As can be seen from Table 3, their numbers differ over time, which means that the data are not pooled in the usual sense. However, this is common to all the studies of combined cross-section and time series data mentioned above. 
The interpretation of the constant has an interesting aspect. Besides the elasticity term (given monopolistic competition between lenders), it perhaps also contains a more basic notion of "moral commitment to debt repayment" which is only the constant part of creditworthiness. It can be interpreted as reflecting the lender's judgement of the borrower's basic disposition to repay debts in general, notwithstanding the economic environment. There is no doubt, that this basic readiness differs among borrowing countries. In equation ( 3 ) the intercept can be written

$$
\alpha_{0}=\left[\frac{\mu}{(\mu-1)}\right]+\alpha^{*}
$$

where $\mu$ denotes the demand elasticity $1 /$ with respect to changes in the spread, and $a^{*}$ reflects the borrower's reputation of repayment.

Unfortunately, the elasticity term remains unidentified. An absolute demand elasticity $(\mu)$ of zero implies $\alpha=\alpha^{*}$, whereas an infinite $\mu$ corresponds to the term in brackets approaching 1 asymptotically from above etc.

Table 5 reports on the regression results obtained from estimating (3) according to the DSCA (equation (2)). In the logarithmic case the intercept is not significantly different from zero. Adding for example the assumption of $\mu=1.25$, this implies a negative value for

$\alpha^{*}=-5$. The economic interpretation is possibly that Israel's record as a conscientious debtor acts as a risk-reducing factor on the lenders' perception of Israel's creditworthiness.

Another interesting conclusion from the empirical results is that most variables determining the spread are linked more to the bankers' perception of short-run liquidity than long run solvency. This is indicated by the fact that most of the relevant macroeconomic variables address the liquidity problem, such as for example, the debt-service ratio (DSRATIO), $2 /$ current nominal per capita income (in dollars) and real per capita reserve holdings (RPCR). $3 /$ Real per capita debt and capital stock bear more information on the solvency aspect. The fact, that the reserve coefficient is approximately four times as large as the debt-coefficient (the variables are of equal denomination), confirms this observation. Of course, one should not conclude that "solvency"

\section{1/ This is discussed in FJ (1977b) on page 26.}

2/ It may be argued that the common debt service ratio does not properly represent the Israeli case, because of the sizeable and steady flow of transfer payments from the U.S. Government and the private sector. Adding these to the export earnings hardly affects the results (Table 6, R5).

3/ Following Dornbusch (1983), debt and reserves are first translated into the domestic currency at the official exchange rate and then deflated by the domestic consumer price index. 
problems do not matter, but rather that the supply of loans as such is conditional upon a basically sound economy in the borrowing country and the risk factor is then largely determined by the liquidity position. Put differently, a bank would probably stop lending altogether, if long run solvency was seriously endangered, but on the other hand liquidity problems may well develop on the background of a perfectly healthy solvency situation. Such an example is described in Cooper and Sachs (1984, p. 8-11).

Furthermore, the spread on a particular loan is certainly influenced by the specific risk of a given firm or institution, separately from the sovereign risk which is common to all the loans. Unfortunately on the former risk, no information is available. The fact that the explanatory power hardly reaches 0.60 is probably due to this source of variation. The dummy variable PUBLIC, which indicates whether the loan has been taken by the Government or one of the semigovernmental agencies on the one hand, or by the private sector on the other hand, shows that the risk factor associated with the public sector is significantly below that of the private sector. Furthermore, the loans received in the Euromarket clearly bear a higher risk premium than those taken in the U.S. capital market. As reported in Table 6, (R6 to R8) the specific loan's maturity (TERM) and loan size (SUM) are statistically insignificant, whereas the grace period seems to increase risk. Admittedly, the use of the these loan-specific variables assumes that they are predetermined.

Instead of the real per capita stock of capital (KPC), we also tried the long run growth trend of exports (GEXP), and alternatively a measure which takes consumption rigidities into account (DSR1). Each one enters the regression satisfactorily, though they alter the other variables significance without affecting $R^{2}$ by much. This may be due to multicollinearity ( $R 1, R 4)$. Substituting the marginal propensity to invest (MPI) for KPC did not improve the regression results compared to Table 4 (R2). As mentioned earlier, the effect of the average maturity of the total debt is somewhat ambiguous. On the one hand Kharas, focusing mainly on solvency problems, attributes an improvement of creditworthiness to longer maturities (DTERM) and on the other hand in the other empirical articles, a predominantly long term debt affects creditworthiness negatively, due to the short term rigidity, created by such precommitments. Our evidence (R3) supports the latter

interpretation. This further confirms the impression, that risk premia reflect 1 iquidity problems more strongly than solvency considerations.

Another problem discussed in FJ (1977b) and also in Edwards (1984) is that of time specific effects. Such effects might exist due to differing market conditions over time. Recalling our previous discussion, monopolistic competition among bankers implies a demandelasticity term in the intercept as in expression (4) Changing market conditions, such as for example sudden large inflows of Petrodollars into the Euromarket, may be approximated by introducing time dummies provided the demand elasticity remain constant. Having assumed an 
information lag of less than one year, this renders our equation just identifiable for most of the lags, despite the fact that the macroeconomic variables are common to all borrowers at a given point in time. Separate time dummies for each year and a trend variable were found to be statistically insignificant. A more selective choice of the years 1973 and 1976 and a period dummy for the years 1980 to 1983 yielded better results. From Appendix III, Table 9, it can be seen, that the year 1973 with the Yom-Kippur war and the oil crisis added significantly to the risk factor. The period dummy for the early $1980 \mathrm{~s}$ al so adds to the risk premium, a fact which may be linked to the general LDC-debt crisis, which took place approximately in this period.

\section{Some policy issues}

The results of this paper can be applied in several ways. First a creditworthiness-index (c) can be derived, which is based on the bankers' sovereign-risk evaluation, as revealed in the interest spread. Such a measure can be usefully applied as a minimum constraint on macroeconomic planning by the debtor country. Second, the estimated regression coefficients allow us to evaluate the effect of certain policies on the marginal cost of foreign capital and on creditworthiness.

Using function (2A) of Appendix I, we calculate $\pi(x)$ or alternatively $c(x)=[1-\pi(x)]$ from the regression in Table 5 . The level of default probability varies with our assumption on the absolute value of the demand elasticity as discussed above. As illustrated in Table 7 the lower the demand elasticity, the lower is the level of default probability $(\pi)$. Given this identification problem of the intercept, the changes in creditworthiness are more reliable than the absolute levels. $1 /$

\section{Conclusions}

The empirical evidence presented here supports the view that bankers evaluate macroeconomic developments by their impact on debt service capacity rather than on the borrower's costs and benefits from debt repudiation. Consequently, the major issue facing the borrowing country is that of monitoring its debt service capacity. In other words, macroeconomic policy decisions have to be taken in consideration of their effect on the country's short run liquidity and long run solvency constraints. One possibility is to define critical values for c or its time path, which can be calculated using the estimated coefficients of regressions like that appearing in Table 5.

1/ This illustrates a major difficulty in comparing creditworthiness indices among different countries, since the index level is very sensitive to the assumption concerning the demand elasticity, which is unidentified. 
In view of the importance of reserves as a determinant of creditworthiness, a debtor country may for instance consider borrowing for the sake of reserve accumulation or reserve-pegging (Edwards, 1984). For this purpose we take the total differential of the reduced form (3) (using the estimated coefficients from Table 5). Since gross debt and reserves enter the regression in real per capita terms, we allow for an equal change in gross debt and foreign exchange reserves. A US $\$ 100$ million loan taken by the Government at a rate of, say, 0.25 percent over the U.S.-prime rate, changes the predicted value of $\ln (r)$ by

$$
\Delta \ln (r)=0.14(\operatorname{RPCD})-0.38(\mathrm{RPCR})-0.11 \text { (DSRATIO) }
$$

Given our earlier assumption of $\mu=5$, such a policy improves creditworthiness from 97.5 to 98.1 for the year 1983 .

This exercise hinges on the assumption, that such reserve pegging is transitory and of moderate size, since otherwise the model parameters will not necessarily remain stable. As mentioned earlier, this improvement in creditworthiness is probably due ot a stronger impact of liquidity aspects on the spread as compared to solvency aspects, the latter affecting the quantity more strongly than the costs of borrowing.

Although the period since 1983 has not been studied here, the present results would suggest an improvement in creditworthiness, due to the sharp fall in the rate of inflation immediately following the stabilization program of 1985 and to the replenishment of foreign exchange reserves since then. 
Table 1. Determinants of Creditworthiness

$$
\text { (signs indicate } \delta \pi / \delta x \text { ) }
$$

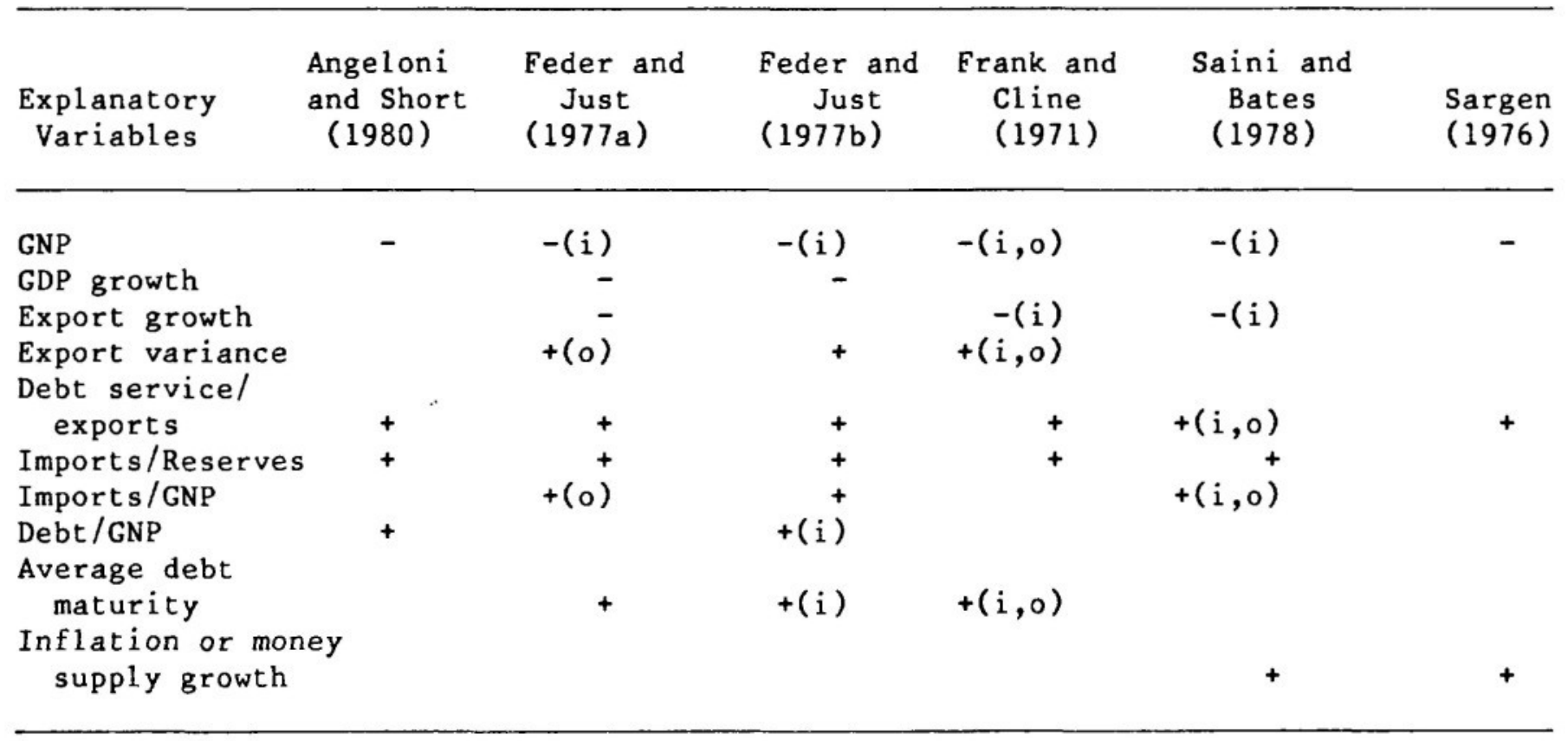


Table 2. Comparison between the two Approaches

\begin{tabular}{lcc}
\hline Variable & $\begin{array}{c}\text { Sign indicates } \\
\text { CBA }\end{array}$ & $\begin{array}{c}\delta \pi / \delta \mathbf{x}) \\
\text { DSCA }\end{array}$ \\
\hline Debt & + & + \\
Reserves (e.g., reserves/GNP) & - & + \\
Openness (e.g., imports/GNP) & - & + \\
Variance of exports (goods and services) & - & $(-)$ \\
Growth of income & - & - \\
Variance of income & - & $(-)$ \\
Capita1 stock per capita & & + \\
Marginal productivity of capital & & + \\
Imports/reserves (reserve adequacy) & & + \\
GNP & & + \\
Inflation rate, money supply growth & $(+)$ & $+1 /$ \\
Nebt-service ratio & $(-)$ & \\
Average debt maturity & & \\
\hline
\end{tabular}

1/ Conceivably ambiguous (see above discussion). 


\begin{tabular}{|c|c|c|c|c|c|c|c|c|c|c|c|c|}
\hline & \multicolumn{3}{|c|}{ Interest Spread } & \multicolumn{3}{|c|}{ Loan Maturity (Months) } & \multicolumn{3}{|c|}{ Grace Period (Months) } & \multicolumn{3}{|c|}{ Loan Size (US\$1,000) } \\
\hline & All & $\begin{array}{c}\text { Floating } \\
\text { loans }\end{array}$ & $\begin{array}{l}\text { Thereof } \\
\text { public }\end{array}$ & All & $\begin{array}{c}\text { Floating } \\
\text { loans }\end{array}$ & $\begin{array}{l}\text { Thereof } \\
\text { public }\end{array}$ & All & $\begin{array}{c}\text { Floating } \\
\text { loans }\end{array}$ & $\begin{array}{l}\text { Thereof } \\
\text { public }\end{array}$ & All & $\begin{array}{c}\text { Floating } \\
\text { loans }\end{array}$ & $\begin{array}{l}\text { Thereof } \\
\text { public }\end{array}$ \\
\hline 1971 & $\begin{array}{l}2.08 \\
(12)\end{array}$ & $\begin{array}{r}1.25 \\
(1)\end{array}$ & $\begin{array}{r}1.25 \\
(1)\end{array}$ & 135 & 103 & 103 & 37 & 12 & 12 & 924 & 675 & 675 \\
\hline 1972 & $\begin{array}{l}1.56 \\
(10)\end{array}$ & $(-)$ & $(-)$ & 213 & 一 & - & 66 & - & - & 4,016 & - & - \\
\hline 1973 & $\begin{array}{l}0.92 \\
(13)\end{array}$ & $\begin{array}{r}1.17 \\
(6)\end{array}$ & $\begin{array}{r}1.00 \\
(5)\end{array}$ & 149 & 128 & 117 & 36 & 8 & 8 & 3,635 & 4,662 & 5,224 \\
\hline 1974 & $\begin{array}{l}0.88 \\
(13)\end{array}$ & $\begin{array}{r}1.80 \\
(5)\end{array}$ & (-) & 143 & 87 & 一 & 40 & 28 & - & 3,782 & 3,207 & 一 \\
\hline 1975 & $\begin{array}{r}-0.90 \\
(5)\end{array}$ & $\begin{array}{r}1.75 \\
(1)\end{array}$ & (-) & 178 & 297 & 一 & 46 & 68 & - & 5,533 & 660 & - \\
\hline 1976 & $\begin{array}{l}1.30 \\
(26)\end{array}$ & $\begin{array}{l}1.23 \\
(11)\end{array}$ & $\begin{array}{r}0.80 \\
(5)\end{array}$ & 78 & 64 & 68 & 36 & 33 & 30 & 2,999 & 1,630 & 2,399 \\
\hline 1977 & $\begin{array}{l}1.25 \\
(35)\end{array}$ & $\begin{array}{l}1.35 \\
(15)\end{array}$ & $\begin{array}{r}1.43 \\
(7)\end{array}$ & 76 & 70 & 74 & 24 & 21 & 11 & 3,243 & 3,558 & 6,245 \\
\hline 1978 & $\begin{array}{l}1.73 \\
(31)\end{array}$ & $\begin{array}{l}1.27 \\
(11)\end{array}$ & $\begin{array}{r}1.06 \\
(8)\end{array}$ & 75 & 54 & 51 & 34 & 22 & 11 & 2,663 & 2,725 & 3,590 \\
\hline 1979 & $\begin{array}{l}0.74 \\
(40)\end{array}$ & $\begin{array}{l}1.22 \\
(30)\end{array}$ & $\begin{array}{l}1.22 \\
(21)\end{array}$ & 45 & 27 & 21 & 23 & 13 & 6 & 2,344 & 1,654 & 2,245 \\
\hline 1980 & $\begin{array}{l}1.22 \\
(81)\end{array}$ & $\begin{array}{l}1.23 \\
(60)\end{array}$ & $\begin{array}{l}1.23 \\
(59)\end{array}$ & 51 & 50 & 50 & 16 & 13 & 12 & 1,016 & 706 & 694 \\
\hline 1981 & $\begin{array}{l}0.80 \\
(77)\end{array}$ & $\begin{array}{l}1.27 \\
(70)\end{array}$ & $\begin{array}{l}1.29 \\
(65)\end{array}$ & 44 & 40 & 39 & 12 & 12 & 10 & 2,269 & 2,019 & 2,070 \\
\hline 1982 & $\begin{array}{l}0.99 \\
(93)\end{array}$ & $\begin{array}{l}1.28 \\
(81)\end{array}$ & $\begin{array}{l}1.21 \\
(63)\end{array}$ & 26 & 19 & 7 & 9 & 6 & 2 & 1,892 & 1,835 & 1,737 \\
\hline 1983 & $\begin{array}{l}1.24 \\
(88)\end{array}$ & $\begin{array}{l}1.39 \\
(75)\end{array}$ & $\begin{array}{l}1.19 \\
(61)\end{array}$ & 19 & 14 & 8 & 12 & 8 & 3 & 1,493 & 1,380 & 1,456 \\
\hline $\begin{array}{l}\text { Al1 } \\
\text { Years* }\end{array}$ & $\begin{array}{r}1.15 \\
(544)\end{array}$ & $\begin{array}{r}1.30 \\
(366)\end{array}$ & $\begin{array}{r}1.22 \\
(295)\end{array}$ & 60 & 36 & 30 & 20 & 11 & 7 & 2,173 & 1,727 & 1,804 \\
\hline
\end{tabular}

*Includes also 20 loans from years 1961 to 1970.

Source: Comptroller of Foreign Exchange, Bank of Israel. 
Table 4. Israel: Comparison of the Performance of CBA and DSCA $1 /$

\begin{tabular}{|c|c|c|}
\hline \multirow{2}{*}{$\begin{array}{l}\text { Dependent Variable: } r \\
\text { Explanatory Variables: }\end{array}$} & \multicolumn{2}{|c|}{ Estimates } \\
\hline & $\overline{\mathrm{CBA}}$ & $\overline{\mathrm{DSCA}}$ \\
\hline Intercept & $\begin{array}{l}-0.201 \\
(-3.2)\end{array}$ & $\begin{array}{l}0.374 \\
(3.0)\end{array}$ \\
\hline RPCD (real debt per capita) & $\begin{array}{l}0.017 \\
(11.5)\end{array}$ & $\begin{array}{l}0.017 \\
(6.7)\end{array}$ \\
\hline RPCR (real reserves per capita) & $\begin{array}{l}-0.058 \\
(-8.0)\end{array}$ & $\begin{array}{l}-0.055 \\
(-6.3)\end{array}$ \\
\hline OPEN (openness) & $\begin{array}{l}0.157 \\
(3.7)\end{array}$ & $\begin{array}{l}0.273 \\
(4.0)\end{array}$ \\
\hline $\begin{array}{l}\text { VGS (variance of goods and services } \\
\text { exports) }\end{array}$ & $\begin{array}{l}4.4 \mathrm{E}-7 \\
(1.4)\end{array}$ & $\begin{array}{l}1.8 \mathrm{E}-6 \\
(4.9)\end{array}$ \\
\hline MPK (marginal product of capital) & $\begin{array}{l}-0.085 \\
(-9.4)\end{array}$ & \\
\hline VRGNP (variance of real GNP) & $\begin{array}{l}0.664 \\
(5.4)\end{array}$ & \\
\hline GRPCY (growth of real GNP) & $\begin{array}{l}0.027 \\
(8.8)\end{array}$ & \\
\hline KPC (real capital stock per capita) & & $\begin{array}{l}-0.013 \\
(-4.1)\end{array}$ \\
\hline DGNPPC (GNP per capita) & & $\begin{array}{l}-0.048 \\
(-4.6)\end{array}$ \\
\hline DSRATIO (debt-service ratio) & & $\begin{array}{l}0.011 \\
(9.2)\end{array}$ \\
\hline CPI (inflation rate) & & $\begin{array}{l}4.7 \mathrm{E}-4 \\
(3.9)\end{array}$ \\
\hline PUBLIC (dummy for public sector loans) & $\begin{array}{l}-0.032 \\
(-6.6)\end{array}$ & $\begin{array}{l}-0.031 \\
(-6.4)\end{array}$ \\
\hline EURO (dummy for Euromarket loans) & $\begin{array}{l}0.033 \\
(3.4)\end{array}$ & $\begin{array}{c}0.031 \\
(3.2)\end{array}$ \\
\hline $\mathrm{R}^{2}$ & 0.586 & 0.593 \\
\hline$F$ - Value & 55.59 & 51.18 \\
\hline Numbers of observations & 363 & 363 \\
\hline
\end{tabular}

1/ Figures in parentheses below the estimates are t-values. 
Table 5. Israel: Regression Results of Equation (3)--The DSCA

Dependent Variable: $\log (r)$

$$
\begin{array}{ll}
\mathrm{R}^{2}= & 0.514 \\
\mathrm{~F}-\text { ratio }= & 37.22
\end{array}
$$

Explanatory Variables:

\begin{tabular}{lllllllllll}
\hline Intercept & RPCD & RCPR & OPEN & VGS & KPC & DGNPPC & DSRATIO & CPI & PUBLIC & EURO \\
\hline-0.53 & 0.14 & -0.38 & 2.76 & $1.8 \mathrm{E}-5$ & -0.12 & -0.38 & 0.11 & $2.3 \mathrm{E}-5$ & -0.12 & 0.37 \\
$(-0.4)$ & $(5.9)$ & $(-4.6)$ & $(4.2)$ & $(5.0)$ & $(-4.1)$ & $(-3.7)$ & $(9.4)$ & $(2.0)$ & $(-2.6)$ & $(4.0)$
\end{tabular}


Table 6. Israel: Selected Regressions

Dependent Variable: $\mathbf{r}$ Regressions: Explanatory Variables:
R1

R2

R3

$\mathrm{R} 4$

R5

R6

R7

R8

\begin{tabular}{|c|c|c|c|c|c|c|c|c|}
\hline Intercept & $\begin{array}{r}0.36 \\
(3.5)\end{array}$ & $\begin{array}{r}-0.10 \\
(-1.6)\end{array}$ & $\begin{array}{l}-1.36 \\
(-3.3)\end{array}$ & $\begin{array}{r}-0.44 \\
(-5.3)\end{array}$ & $\begin{array}{r}0.45 \\
(3.6)\end{array}$ & $\begin{array}{r}0.35 \\
(2.7)\end{array}$ & $\begin{array}{r}0.36 \\
(2.8)\end{array}$ & $\begin{array}{r}0.37 \\
(3.0)\end{array}$ \\
\hline RPCD & $\begin{array}{l}-7.0 E^{-4} \\
(-0.3)\end{array}$ & $\begin{array}{r}0.01 \\
(5.7)\end{array}$ & $\begin{array}{r}0.02 \\
(7.3)\end{array}$ & $\begin{array}{l}9.4 E^{-4} \\
(0.4)\end{array}$ & $\begin{array}{r}0.01 \\
(5.1)\end{array}$ & $\begin{array}{r}0.02 \\
(6.6)\end{array}$ & $\begin{array}{r}0.02 \\
(6.5)\end{array}$ & $\begin{array}{r}0.02 \\
(6.7)\end{array}$ \\
\hline RPCR & $\begin{array}{r}-0.03 \\
(-3.8)\end{array}$ & $\begin{array}{r}-0.02 \\
(-2.0)\end{array}$ & $\begin{array}{r}-0.04 \\
(-4.8)\end{array}$ & $\begin{array}{l}-6.7 \mathrm{E}-3 \\
(-0.8)\end{array}$ & $\begin{array}{r}-0.06 \\
(-6.2)\end{array}$ & $\begin{array}{r}-0.05 \\
(-6.2)\end{array}$ & $\begin{array}{r}-0.05 \\
(-5.9)\end{array}$ & $\begin{array}{r}-0.05 \\
(-6.3)\end{array}$ \\
\hline OPEN & $\begin{array}{r}0.04 \\
(1.2)\end{array}$ & $\begin{array}{r}0.06 \\
(1.7)\end{array}$ & $\begin{array}{r}0.54 \\
(6.0)\end{array}$ & $\begin{array}{r}0.24 \\
(4.4)\end{array}$ & $\begin{array}{r}0.14 \\
(2.1)\end{array}$ & $\begin{array}{r}0.27 \\
(4.0)\end{array}$ & $\begin{array}{r}0.26 \\
(3.9)\end{array}$ & $\begin{array}{r}0.28 \\
(4.1)\end{array}$ \\
\hline VGS & $\begin{array}{l}9.3 \mathrm{E}-7 \\
(3.4)\end{array}$ & $\begin{array}{l}6.5 E-7 \\
(2.2)\end{array}$ & $\begin{array}{l}1.5 \mathrm{E}-6 \\
(4.1)\end{array}$ & $\begin{array}{l}7.2 \mathrm{E}-7 \\
(2.4)\end{array}$ & $\begin{array}{l}1.6 \mathrm{E}-6 \\
(4.3)\end{array}$ & $\begin{array}{l}1.8 \mathrm{E}-6 \\
(4.9)\end{array}$ & $\begin{array}{l}1.8 \mathrm{E}-6 \\
(5.0)\end{array}$ & $\begin{array}{l}1.9 \mathrm{E}-6 \\
(5.0)\end{array}$ \\
\hline $\mathrm{KPC}$ & & & $\begin{array}{r}-0.01 \\
(-4.1)\end{array}$ & & $\begin{array}{l}-7.9 E-3 \\
(-2.6)\end{array}$ & $\begin{array}{r}-0.01 \\
(-4.0)\end{array}$ & $\begin{array}{r}-0.01 \\
(-4.1)\end{array}$ & $\begin{array}{r}-0.01 \\
(-4.2)\end{array}$ \\
\hline DSRI & & & & $\begin{array}{r}0.08 \\
(3.8)\end{array}$ & & & & \\
\hline GEXP & $\begin{array}{l}-7.7 \mathrm{E}-3 \\
(-5.3)\end{array}$ & & & & & & & \\
\hline MPI & & $\begin{array}{r}-0.23 \\
(-2.3)\end{array}$ & & & & & & \\
\hline DGNPPC & $\begin{array}{r}-0.02 \\
(-1.6)\end{array}$ & $\begin{array}{r}-0.09 \\
(-4.5)\end{array}$ & $\begin{array}{l}-1.2 \mathrm{E}-3 \\
(-0.1)\end{array}$ & $\begin{array}{r}-0.04 \\
(-3.3)\end{array}$ & $\begin{array}{r}-0.07 \\
(-6.9)\end{array}$ & $\begin{array}{r}-0.05 \\
(-4.5)\end{array}$ & $\begin{array}{r}-0.05 \\
(-4.2)\end{array}$ & $\begin{array}{r}-0.05 \\
(-4.6)\end{array}$ \\
\hline DSRATIO & $\begin{array}{l}1.1 \mathrm{E}-3 \\
(0.5)\end{array}$ & $\begin{array}{r}0.01 \\
(8.1)\end{array}$ & $\begin{array}{r}0.02 \\
(8.3)\end{array}$ & $\begin{array}{r}0.02 \\
(9.9)\end{array}$ & & $\begin{array}{r}0.01 \\
(9.2)\end{array}$ & $\begin{array}{r}0.01 \\
(9.2)\end{array}$ & $\begin{array}{r}0.01 \\
(9.2)\end{array}$ \\
\hline DSIRATIO & & & & & $\begin{array}{r}0.83 \\
(8.2)\end{array}$ & & & \\
\hline DIERM & & & $\begin{array}{r}1.43 \\
(4.4)\end{array}$ & & & & & \\
\hline CPI & $\begin{array}{l}2.6 \mathrm{E}-4 \\
(2.4)\end{array}$ & $\begin{array}{l}5.7 \mathrm{E}-4 \\
(3.3)\end{array}$ & $\begin{array}{l}7.0 \mathrm{E}-4 \\
(5.3)\end{array}$ & $\begin{array}{l}9.3 \mathrm{E}-5 \\
(0.7)\end{array}$ & $\begin{array}{l}5.8 \mathrm{E}-4 \\
(4.7)\end{array}$ & $\begin{array}{l}4.5 \mathrm{E}^{-4}-4 \\
(3.6)\end{array}$ & $\begin{array}{l}4.3 E^{-4} \\
(3.4)\end{array}$ & $\begin{array}{l}4.8 \mathrm{E}-4 \\
(3.9)\end{array}$ \\
\hline PUBLIC & $\begin{array}{r}-0.03 \\
(-6.1)\end{array}$ & $\begin{array}{r}-0.03 \\
(-7.0)\end{array}$ & $\begin{array}{r}-0.02 \\
(-5.1)\end{array}$ & $\begin{array}{r}-0.02 \\
(-5.1)\end{array}$ & $\begin{array}{r}-0.03 \\
(-7.0)\end{array}$ & $\begin{array}{r}-0.03 \\
(-6.1)\end{array}$ & $\begin{array}{r}-0.03 \\
(-5.2)\end{array}$ & $\begin{array}{r}-0.03 \\
(-6.5)\end{array}$ \\
\hline EURO & $\begin{array}{r}0.03 \\
(2.9)\end{array}$ & $\begin{array}{r}0.02 \\
(1.9)\end{array}$ & $\begin{array}{r}0.04 \\
(3.8)\end{array}$ & $\begin{array}{r}0.04 \\
(4.3)\end{array}$ & $\begin{array}{r}0.03 \\
(2.6)\end{array}$ & $\begin{array}{r}0.03 \\
(3.2)\end{array}$ & $\begin{array}{r}0.03 \\
(3.2)\end{array}$ & $\begin{array}{r}0.03 \\
(3.4)\end{array}$ \\
\hline TERM & & & . & & & $\begin{array}{l}3.6 \mathrm{E}-5 \\
(0.9)\end{array}$ & & \\
\hline GRACE & & & & & & & $\begin{array}{l}1.5 \mathrm{E}-4 \\
(1.1)\end{array}$ & \\
\hline SUM & & & & & & & & $\begin{array}{l}8.0 \mathrm{E}-7 \\
(1.4)\end{array}$ \\
\hline $\mathrm{R}^{2}$ & 0.60 & 0.58 & 0.61 & 0.60 & 0.58 & 0.59 & 0.59 & 0.59 \\
\hline F-Value & 53.6 & 48.4 & 50.7 & 52.4 & 47.8 & 46.6 & 46.7 & 46.8 \\
\hline
\end{tabular}


Table 7. Israel: Estimates of Creditworthiness (c) and its Percentage Change over Time

\begin{tabular}{llllr}
\hline & \multicolumn{2}{c}{ Level } & \multicolumn{2}{c}{ Percent Change of $c$} \\
\cline { 2 - 5 } & $\mu=0$ & $\mu=5$ & & $\mu=5$ \\
1971 & 85.34 & 83.31 & 6.7 & \\
1972 & 91.03 & 97.25 & -2.1 & -0.6 \\
1973 & 89.14 & 96.63 & -5.6 & -1.8 \\
1974 & 84.19 & 94.89 & -2.9 & -0.9 \\
1975 & 81.76 & 93.99 & 7.2 & 2.3 \\
1976 & 87.63 & 96.11 & 1.4 & 0.4 \\
1977 & 88.85 & 96.53 & 4.5 & 1.4 \\
1978 & 92.87 & 97.85 & 1.8 & 0.5 \\
1979 & 94.56 & 98.38 & 1.4 & 0.4 \\
1980 & 95.89 & 98.79 & -1.0 & -0.3 \\
1981 & 94.95 & 98.50 & -2.2 & -0.7 \\
1982 & 92.89 & 97.85 & -1.1 & -0.4 \\
1983 & 91.83 & 97.51 & & \\
\hline
\end{tabular}


The expected profit ( $E P^{r}$ ) from one dollar lent to a risky borrowing country can be written as the sum of outcomes, each weighted by its probability of occurrence in this simple model. With probability $(1-\pi)$, the banker expects either to earn a promised interest ( $i$ ) on one dollar lent or else to lose his initial investment and the interest with default probability $\pi$. In case of full repayment, the interest earned at the end of the period is discounted at the safe rate of interest $(i *)$.

$$
E P^{r}=(1-\pi)\left(-1+\frac{1+i}{1+i^{*}}\right)+\pi(-1+0)
$$

The assumption of risk neutrality $1 /$ implies that expected profits from risky loans must equal, those from nonrisky loans, which is zero by definition. $P=-1+\frac{1+1^{*}}{1+i^{*}}=0$

Therefore in a competitive loan market with risk neutral and (expected) profit-maximizing lenders, normal profits (which include management fees, etc.) are eventually driven to zero, where $\mathrm{EP}^{r}=0$ or

$$
(1-\pi)\left(-1+\frac{1+i}{1+i *}\right)-\pi=0
$$

\section{Rearranging we get}

$$
r=\frac{i-i *}{1+i^{*}}=\frac{\pi(x)}{1-\pi(x)},
$$

where $r$ reflects the discounted value of the interest spread. In equilibrium, $r$ equals the odds of default. The vector of determinants of default probability is denoted by $x$. Following FJ (1977b), the function $\pi$ is assumed to depend on $x$ according to the logistic form, i.e.,

$$
\pi(x)=\frac{\exp \left(\alpha_{0}+\sum_{k=1}^{K} \alpha_{k} x_{k}\right)}{1+\exp \left(\alpha_{0}+\sum_{k=1}^{1} \alpha_{k} x_{k}\right)}
$$

This function's boundedness between zero and one for all values of $x$, renders it suitable to represent a probability function. It also lends

1/ This assumption is chosen for expositional purpose only, and may be relaxed by another assumption e.g., risk aversion. See for example Feder and Just (1980), where it is shown that, given the small size of each Euromarket transaction relative to the lender's assets, the risk aversion premium is negligible relative to the variation in the spread $(i-i *)$. 
FIGURE 1

(a)

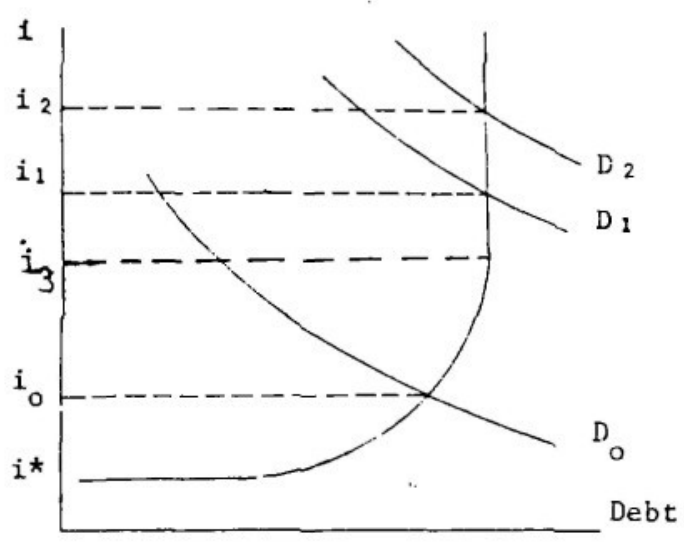

(b)

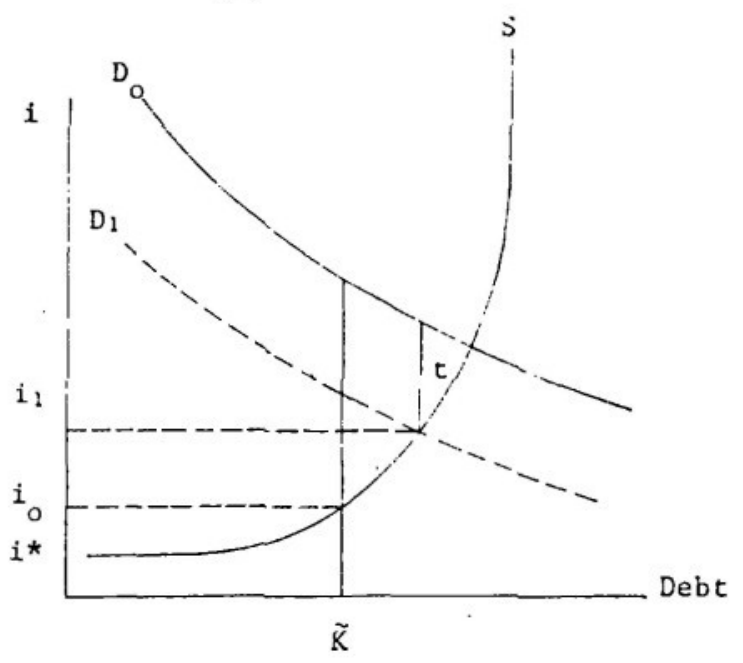


Download Date: 4/1/2005 - 10:05 AM

Current Classification: Available to the Public

User:RRAFOLS
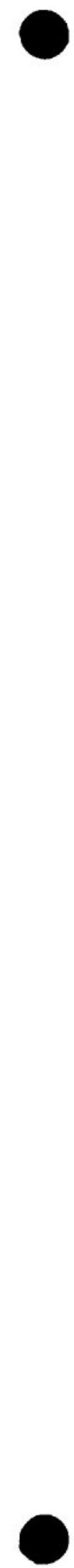

. 列

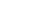
. . 
itself easily to regression analysis, since the logarithm of equation (6) can be written

$$
\ln \left[\frac{i-i^{*}}{1+i^{*}}\right]=\ln \left[\frac{\pi(x)}{1-\pi(x)}\right]=\alpha_{0}+\sum_{k=1}^{K} \alpha_{k} x_{k}
$$

FJ (1977b) assume, that the Euroloan-market is approximated more accurately by monopolistic competition. Maximizing the lender's expected utility under the assumption, that he knows the borrowing country's demand elasticity $\left(\mu=\left|i L_{i} / L\right|\right)$, FJ's respective expression to our equation (8) includes also an element of the demand elasticity and one of risk aversion in the intercept. The latter vanishes in case of risk neutrality. Their study is on cross-sectional data of different countries. In order to account for differing demand elasticities in different countries they apply the variance-components approach, which combines cross-section and time series data, (see also Edwards (1984). Since our data differ in this respect, there is no need to split up the elasticity term in case of a monopolistic market structure, if this elasticity is stable over the analyzed period.

The existence of quantity constraints on loans may in some instances impait on the inference on sovereign risk from observed interest spreads. Such quotas may be due to different sources, namely to self-imposed quantity constraints by lenders, sometimes referred to as "country limits" or else to the borrowing country's capital controls policy. Endogenously determined country limits by the lending banks are discussed in Eaton and Gersovitz (1981a), Sachs and Cohen (1982), Sachs (1983) and others. Obviously, once a borrowing country has reached its country limit with all the lending banks, then any shifts of the demand curve will change the spread without altering default risk. Several examples are illustrated in the following diagrams.

Figure 1(a) demonstrates the case of lender-imposed country limits, where the spread $\left(i_{0}-i *\right)$ does reflect country risk while $\left(i_{1}-i *\right)$ does not, since the correct measure in both cases would be $i_{3}-i *$. $1 /$ In Figure 1 (b) the alternative instruments of capital control, namely a quota $(K)$ or a capital import tax $(t)$ do not affect the spread as a signal for country risk, as long as the borrowers have not reached the credit ceilings.

This study, therefore, implicitly assumes that the total market's credit ceiling for Israeli loan demand has not been reached during the observed period. This seems to be an appropriate assumption.

1/ Notice however that even if credit ceilings are reached, changes in the spread, generated by, say, a reduction in credit ceilings, still remain relevant signals for changes in creditworthiness. 
Definitions of variables:

A given variable's trend growth or variance from trend is estimated as follows:

(a) For growth rates of real GNP per capita (GRPCY) and real exports (GEXP)

years

$$
\ln \left(y_{t}\right)=a+b(t)+u_{1 t} \quad, t=\text { quarters over } 5
$$

growth of $y=\left[(b+1)^{4}-1\right] \times 100$

(b) For variances

$y_{t}=a+b(t)+u_{2 t}, t=$ quarters over 5 years.

$\operatorname{Var}(y)=\frac{1}{n-2} \sum_{t}\left(y-y_{t}\right)^{2}$

$\operatorname{Var}(y)=$ VGS, VRGNP respectively, where $G S=$ balance on goods and services (current dollars), GNPR = Real GNP (1980 Shekels).

(c) Other definitions:

$i=$ interest rate on the loan contract.

$i^{*}=$ LIBOR for loans received in the Eurodollar market or PRIME-rate for loans received in the US-capital market.

$\pi=$ probability of default.

$c=$ creditworthiness index. $c=(1-\pi) \times 100$.

where

RPCD $=$ real per capita debt $=(\mathrm{E} / \mathrm{CP}) \times$ gross debt/population,

$\mathrm{E}=$ official exchange rate, $\mathrm{CP}=$ consumer price index.

RPCR $=$ real per capita official reserves $=(E / C P) \times$ (official reserves/population)

GNPPC = per capita real quarterly GNP (1980 prices)

over 5 years.

VRGNP = Variance of quarterly real GNP from trend, estimated

DGNPPC $=$ Nominal yearly per capita GNP in dollars, translated into dollars on a quarterly basis. dollars.

DGNPY = yearly aggregated quarterly GNP, denominated in 
investment).

OPEN $=$ (imports + exports of goods and services $) /$ DGNPY.

MPK = (change in yearly nominal GNP / (yearly nominal net

$$
\begin{aligned}
& \text { MPI }=1 / \text { MPK. } \\
& \text { KPC }=\text { capital stock per capita at } 1980 \text { prices. } \\
& \text { CPI = annual change in the Consumer Price Index } \\
& \text { DS1 = yearly amortization of total debt + total interest }
\end{aligned}
$$

payments.

$$
\mathrm{DSR} 1=\mathrm{DS} 1 / \mathrm{DSC}
$$

where

interest payments.

DS = yearly amortization of long and medium term debt + total

DSC $=$ Debt service capacity constrained by a downward rigidity in aggregate consumption. For the formula, see 0. Liviatan (1984, p. $810)$.

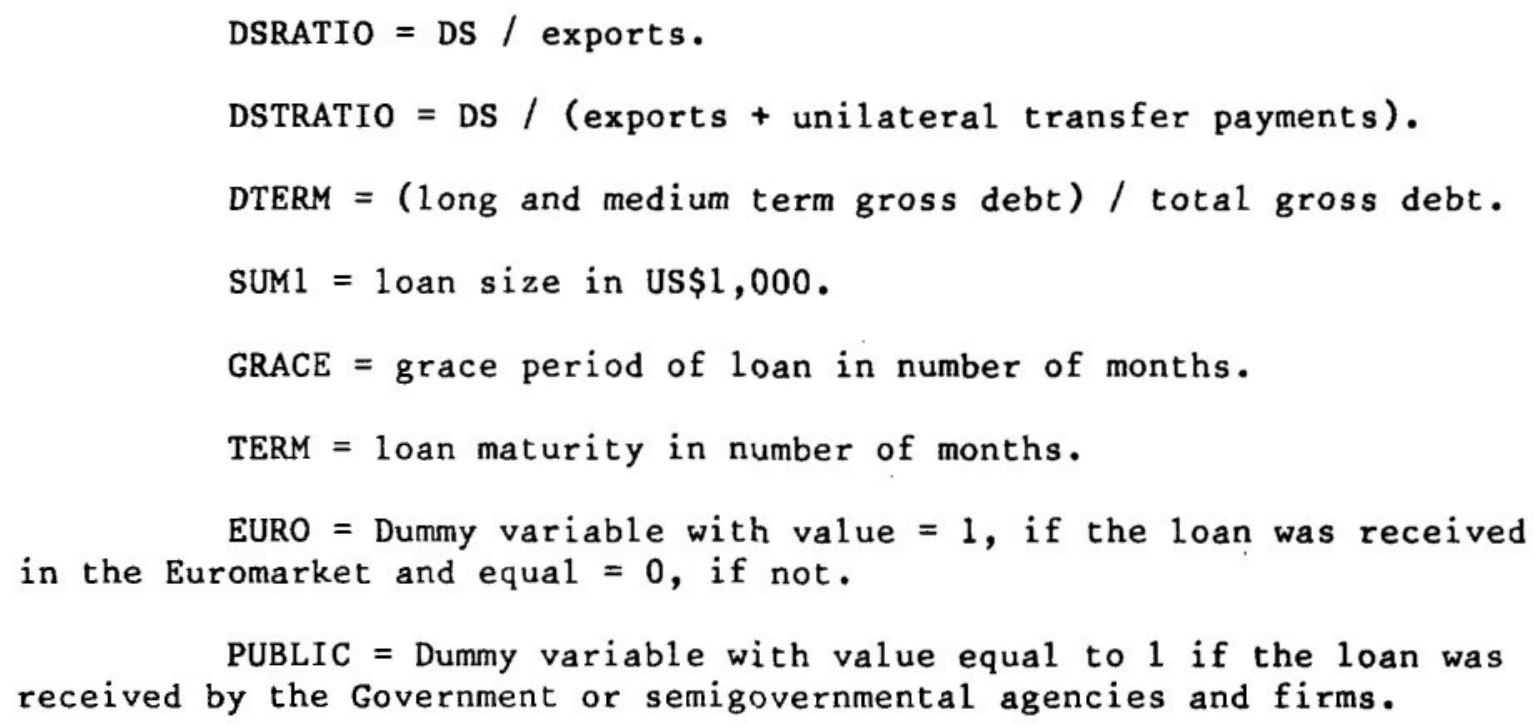

Sources: The interest spread $r$, the loan amounts, grace periods and maturities are from the Foreign Exchange Comptroller at the Bank of Israel. The macroeconomic data are from the Central Bureau of Statistics, Israel. 
Table 8. Israel: Different Assumptions on the Information-Lag Dependent Variable: $r$

\begin{tabular}{|c|c|c|c|c|}
\hline & \multicolumn{4}{|c|}{ Number of Days } \\
\hline & 90 & 180 & 270 & 360 \\
\hline Intercept & $\begin{array}{l}-0.40 \\
(-1.1)\end{array}$ & $\begin{array}{r}-1.16 \\
(-3.0)\end{array}$ & $\begin{array}{l}-1.36 \\
(-3.3)\end{array}$ & $\begin{array}{r}0.82 \\
(1.4)\end{array}$ \\
\hline RPCD & $\begin{array}{l}3.7 \mathrm{E}-3 \\
(1.6)\end{array}$ & $\begin{array}{l}3.8 \mathrm{E}-3 \\
(1.7)\end{array}$ & $\begin{array}{r}0.02 \\
(7.3)\end{array}$ & $\begin{array}{l}2.0 \mathrm{E}-3 \\
(0.6\end{array}$ \\
\hline RPCR & $\begin{array}{l}-0.02 \\
(-2.4)\end{array}$ & $\begin{array}{l}-3.8 \mathrm{E}-3 \\
(-0.4)\end{array}$ & $\begin{array}{r}-0.04 \\
(-4.8)\end{array}$ & $\begin{array}{l}-0.02 \\
(-2.0)\end{array}$ \\
\hline OPEN & $\begin{array}{l}-0.03 \\
(-0.3)\end{array}$ & $\begin{array}{r}0.32 \\
(2.9)\end{array}$ & $\begin{array}{r}0.54 \\
(6.0)\end{array}$ & $\begin{array}{r}0.03 \\
(0.3)\end{array}$ \\
\hline VGS & $\begin{array}{l}2.9 \mathrm{E}-7 \\
(0.6)\end{array}$ & $(1.7 \mathrm{E}-6$ & $\begin{array}{l}1.5 \mathrm{E}-6 \\
(4.1)^{-6}\end{array}$ & $\begin{array}{l}1.7 E-6 \\
(3.9)\end{array}$ \\
\hline KPC & $\begin{array}{l}2.3 \mathrm{E}-3 \\
(0.8)\end{array}$ & $\begin{array}{l}-5.2 E^{-3} \\
(-1.5)\end{array}$ & $\begin{array}{r}-0.01 \\
(-4.1)\end{array}$ & $\begin{array}{l}-5.6 \mathrm{E}-3 \\
(-1.7)\end{array}$ \\
\hline DGNPPC & $\begin{array}{l}-0.01 \\
(-0.7)\end{array}$ & $\begin{array}{r}0.03 \\
(1.6)\end{array}$ & $\begin{array}{l}-1.2 \mathrm{E}-3 \\
(-0.08)\end{array}$ & $\begin{array}{l}-0.01 \\
(-0.9)\end{array}$ \\
\hline DSRATIO & $\begin{array}{l}6.2 \mathrm{E}-3 \\
(2.5)\end{array}$ & $\begin{array}{r}0.02 \\
(5.5)\end{array}$ & $\begin{array}{r}0.02 \\
(8.3)\end{array}$ & $\begin{array}{l}8.5 \mathrm{E}-3 \\
(2.7)\end{array}$ \\
\hline DTERM & $\begin{array}{r}0.44 \\
(1.7)\end{array}$ & $\begin{array}{r}1.08 \\
(3.4)\end{array}$ & $\begin{array}{r}1.43 \\
(4.4)\end{array}$ & $\begin{array}{r}-0.73 \\
(-1.6)\end{array}$ \\
\hline CPI & $\begin{array}{l}1.2 \mathrm{E}-5 \\
(0.1)\end{array}$ & $\begin{array}{l}9.4 \mathrm{E}-5 \\
(0.9)\end{array}$ & $\begin{array}{l}7.0 \mathrm{E}-4 \\
(5.3)^{2}\end{array}$ & $\begin{array}{l}3.4 \mathrm{E}-4 \\
(1.7)\end{array}$ \\
\hline PUBLIC & $\begin{array}{r}-0.04 \\
(-6.6)\end{array}$ & $\begin{array}{r}-0.03 \\
(-5.5)\end{array}$ & $\begin{array}{l}-0.02 \\
(-5.1)\end{array}$ & $\begin{array}{r}-0.04 \\
(-7.6)\end{array}$ \\
\hline EURO & $\begin{array}{r}0.02 \\
(2.3)\end{array}$ & $\begin{array}{r}0.03 \\
(3.1)\end{array}$ & $\begin{array}{r}0.04 \\
(3.8)\end{array}$ & $\begin{array}{r}0.03 \\
(2.8)\end{array}$ \\
\hline $\mathrm{R}^{2}$ & 0.50 & 0.49 & 0.61 & 0.54 \\
\hline F-Value & 31.7 & 30.8 & 50.7 & 37.5 \\
\hline
\end{tabular}


Table 9. Israel: Time Dummies

Dependent variable: $\ln (r)$ Explanatory variables:

\begin{tabular}{|c|c|c|c|}
\hline Intercept & $\begin{array}{r}-102.68 \\
(-1.2)\end{array}$ & TREND & $\begin{array}{r}0.05 \\
(1.2)\end{array}$ \\
\hline $\mathbf{R P C D}$ & $\begin{array}{r}0.17 \\
(6.0)\end{array}$ & D73 & $\begin{array}{r}0.63 \\
(2.3)\end{array}$ \\
\hline RPCR & $\begin{array}{r}-0.48 \\
(-4.6)\end{array}$ & D76 & $\begin{array}{r}0.15 \\
(0.9)\end{array}$ \\
\hline OPEN & $\begin{array}{r}3.53 \\
(4.0)\end{array}$ & $\mathrm{D} 80 \mathrm{a}$ & $\begin{array}{r}0.12 \\
(1.2)\end{array}$ \\
\hline VGS & $\begin{array}{l}2.4 \mathrm{E}-5 \\
(5.5)\end{array}$ & & \\
\hline $\mathrm{KPC}$ & $\begin{array}{r}-0.15 \\
(-4.7)\end{array}$ & & \\
\hline DGNPPC & $\begin{array}{r}-0.56 \\
(-4.4)\end{array}$ & & \\
\hline DSRATIO & $\begin{array}{r}0.09 \\
(5.2)\end{array}$ & & \\
\hline CPI & $\begin{array}{l}3.2 \mathrm{E}-3 \\
(2.5)\end{array}$ & & \\
\hline PUBLIC & $\begin{array}{r}-0.13 \\
(-2.8)\end{array}$ & & \\
\hline EURO & $\begin{array}{r}0.41 \\
(4.3)\end{array}$ & & \\
\hline
\end{tabular}




\section{References}

Angeloni, Ignazio, and Brock K. Short, "The Impact of country risk Assessment on Eurocurrency Interest Spreads: A Cross-Section Analysis" (unpublished, International Monetary Fund, December 30,1980$)$.

Avramovic, Dragoslav, et al., Economic Growth and External Debt (Johns Hopkins Press, Baltimore, 1964).

Bade, R., "Optimal Growth and Foreign Borrowing with Restricted Mobility of Foreign Capital," International Economic Review, Vol. 13 (No. 3, October 1972), pp. 544-552.

Bardhan, Pranab K., "Optimum Foreign Borrowing," in Essays on the Theory of Optimal Economic Growth, ed. by Karl Shel1 (M.I.T. Press, 1967), pp. 117-28.

Cooper, Richard N., and Jeffrey Sachs, "Borrowing Abroad: The Debtor's Perspective," National Bureau of Economic Research, Working Paper No. 1427 (August 1984).

Dornbusch, Rudiger, "Consumption Opportunities and Real Value of the External Debt," Journal of Development Economics, No. 10, (NorthHolland Publishing Company, 1982), pp. 93-101.

Eaton, Jonathan, and Mark Gersovitz, (1981 a), "Debt with Potential Repudiation: Theoretical and Empirical Analysis," Review of Economic Studies, Vol. 48 (April 1981), pp. 289-309.

, (1981 b), Poor-Country Borrowing in Private Financial Markets and the Repudiation Issue, Princeton Studies in International Finance, No. 47, (International Finance Section, Princeton University, June 1981).

Edwards, Sebastian, "LDC's Foreign Borrowing and Default Risk: An Empirical Investigation 1976-1980," American Economic Review, Vo1. 74 (September 1984), pp. 726-734.

Feder, Gershon, and Richard E. Just (1977 a), "A Study of Debt Servicing Capacity Applying Logit Analysis," Journal of Development Economics, Vol. 4 (March 1977), pp. 25-38.

(1977 b), "An Analysis of Credit Terms in the Eurodollar Market," European Economic Review, Vol. 9 (May 1977), pp. 221-243.

(1980), A Model for Analyzing Lenders' Perceived Risk, Applied Economics, Vol. 12, pp. 125-144. 
Feder, Gershon, and Knud Ross, "Risk Assessments and Risk Premiums in the Eurodollar Market," Journal of Finance, Vol. 37 (June 1982), pp. 679-91.

Frank, Charles R., Jr., and.William R. Cline, "Measurement of Debt Servicing Capacity: An Application of Discriminant Analysis," Journal of International Economics, Vol. 1 (August 1971), pp. 327-344.

Freeman, R., "Optimal International Borrowing with default," International Finance Discussion Papers, No. 129 (1979).

Hamada, Koichi, "Optimal Capital Accumulation by an Economy Facing an International Capital Market," Journal of Political Economy,

Vo1. 77 (Part II, July/August 1969), pp. 684-697.

Hanson, James A., "Optimal International Borrowing and Lending," American Economic Review, Vol. 64 (September 1974), pp. 616-630.

Kharas, Homi, "The Long Run Creditworthiness of Developing Countries: Theory and Practice," Quarterly Journal of Economics (August 1984).

Liviatan, Oded, "A Macro-Absorption Approach for Estimating the Foreign Debt Burden," Economic Development and Cultural Change, Vol. 32, No. 4, (Chicago: University of Chicago Press, July 1984), pp. 803-818.

Mayo, Alice L., and Anthony G. Barrett, "An Early-Warning Model for Assessing Developing-Country Risk," Ch. 12 in Financing and Risk in Developing Countries, ed. by Stephen Goodman (New York, 1978), PP. 81-87.

McDonald, Donough C., "Debt Capacity and Developing Country Borrowing: A Survey of the Literature," International Monetary Fund Staff Papers, Vol. 29, (No. 4, December 1982).

Sachs, Jeffrey D., "Theoretical Issues in International Borrowing," Princeton Studies in International Finance, No. 54, (International Finance Section, Princeton University, 1984).

, and Daniel Cohen, "LDC Borrowing with Default Risk," Working Paper No. 925, (National Bureau of Economic Research July 1982).

Saini, Krishan, and Philip Bates, "Statistical Techniques for Determining Debt-Servicing Capacity for Developing Countries: Analytical Review of the Literature and Further Empirical Results," Research Paper No. 7818 (New York: Federal Reserve Bank of New York, September 1978). 
Sargen, Nicholas P., "Commercial Bank Lending to Developing Countries," Economic Review, (California: Federal Reserve Bank of San Francisco, Spring 1976).

Sargen, Nicholas P., "Economic Indicators and Country Risk Appraisal," Economic Review, (California: Federal Reserve Bank of San Francisco, Fal1 1977). 